\title{
The Level of Fatigue in Children with Leukemia
}

\author{
Umi Hanik Fetriyah $^{1}$, Sitti Khadijah ${ }^{2}$, Novia Aprillia ${ }^{3}$ \\ \{umihanik@unism.ac.id\} \\ Nurse Profession Program, Faculty of Health, Sari Mulia University, Indonesia ${ }^{1}$ \\ English Program, Faculty of Humaniora, Sari Mulia University, Indonesia ${ }^{2}$ \\ Bachelor Nursing Program, Health Science High School Sari Mulia, Indonesia ${ }^{3}$
}

\begin{abstract}
The management of leukemia in child take long time, this causes physical effects. Fatigue is one of the physical effects of chemotherapy. The child's fatigue results in increase patient morbidity, anxiety, depression and even a decrease in quality of life. Fatigue must be immediately assessed and handled by nurses to improve their quality of life. Several factors that influence it such us sex, age, length of treatment, and hemoglobin value. Objective: To analyze the level of fatigue and describe the level of fatigue based on sex, age, length of treatment and hemoglobin value. Method: This research is quantitative descriptive using cross sectional design. Sampling technique was done by total sampling. The sample is 44 children with acute lymphoblastic leukemia (ALL) who are undergoinging chemotherapy at Ulin General Hospital, Banjarmasin, Indonesia. The analysis test is univariate. Result: The children have level of mild fatigue were 20 people $(45.5 \%)$, and heavy fatigue were 6 people $(13.6 \%)$. The male child and heavy fatigue were $9,09 \%$. The children age is $2-6$ years old with heavy fatigue were $11.36 \%$. The children who have treatment duration $<2$ years with heavy fatigue were $9,09 \%$. The children who have hemoglobin values $1-10 \mathrm{mg} / \mathrm{dL}$ and heavy fatigue were $9,09 \%$. Conclusion: The children who felt fatigue majority is male sex, 2-6 years old, duration of treatment $<2$ years and less $10 \mathrm{mg} / \mathrm{dl}$ hemoglobin values. Recommendation for nurse to identify the level of fatigue since children with leukemia undergoinging chemotherapy to improve quality of life quality of nursing care and patient centered care for child with leukemia.
\end{abstract}

Keyword: Children, Fatigue, Hemoglobin Value, Length of Treatment, Leukemia, Sex

\section{Introduction}

Cancer is a disease that can occur in children. The incidence of cancer in children is increasing and becoming one of the causes of death. The world's cancer deaths will continue to rise if the cancer is not treated properly. World Health Organization in 2030 estimated that there were 13.1 million deaths will occur as a result of cancer [1].

Classification of leukemia include acute mielogenus leukemia (AML), chronic mielogenus leukemia (CML), acute lymphoblastic leukemia (ALL) [2]. The cause of leukemia is as yet unknown. However, some research there are some risk factors that can lead to leukemia including the use of pesticides, the electric field, history of miscarriage in women, radiation, chemicals (benzene), viruses, genetic disorders, maternal age older relative in childbirth, mothers who smoke while pregnancy, alcohol consumption during pregnancy, the magnetic field, the work of parents, birth weight, birth order and prenatal radiation [3]. 
Management of leukemia one of them is chemotherapy. Chemotherapy aims to kill cancer cells with a variety of drugs (neoplastic agent). Effects of chemotherapy one of which is fatigue (tiredness). The level of fatigue in children with cancer is moderate, light and heavy[4].The impact of fatigue in children are experiencing memory loss or short-term memory, difficulty learning, less interaction while playing with their peers compared to healthy children.

The results of the study [5] In 2009 the younger children (> 9 years) revealed that fatigue affects their ability in physical activity. The results of the study [6] revealed that boys have a higher risk of leukemia cancer than women). Children who suffer from ALL should be long enough maintenance therapy for 2-3 years[7]. Results of research Sharon et al [6] revealed that children with leukemia cancer of bone marrow failure usually occurs with hemoglobin levels of 5-10 g / dL. Results of research Yeh et al., 2008 [8] found that the hemoglobin value and significantly related to fatigue.

Nurses have an important role in the treatment of children with cancer through the process from start nursing care assessment, data analysis, intervention, implementation and evaluation. The purpose of nursing care in children undergoinging cancer treatment primarily is to help children achieve partial or complete remission of the disease.

Results of preliminary studies conducted on October 20, 2017 - October 23, 2017The space-Oncology Hospital Hemato obtained Ulin Banjarmasin ALL data on the number of cancer patients undergoinging chemotherapy in January-December 2015 as many as 132 people (0-14 Years) consisting of 75 men - men and 66 women, 9 person (> 15 years). Months from January to December 2016 which ALL suffer as many as 419 people (0-14 years old) is composed of 280 men and 159 women, 20 people (> 15 years). Months from January to September 2017 suffering from ALL 262 persons (0-14 years) consisting of 169 men and 107 women, 14 (> 15 years). The results obtained from the interviews of children diagnosed with cancer who underwent treatment and care of 7 people say that the often tired when doing light activity.

\section{Research Methods}

The method used in this research is descriptive research with cross sectional design analysis techniques with quantitative approach. Data analysis is a cross sectional study in which the variables which include the risk factors and variables that include the effects observed at once at the same time [9].

The population in this study were all children ALL cancer and underwent chemotherapy in hemato-oncology hospital room Ulin Banjarmasin totaling 44 people. The sample used in this study was the son of ALL cancer and underwent chemotherapy in the room hematooncology sampling technique used in this study is total sampling. Total sampling is a sampling technique in which the number of samples is equal to the population [10].

Analysis of data using univariate analysis. The data used are primary and secondary data. The independent variables were age, sex, duration of treatment and hemoglobin values while the dependent variable is the level of fatigue. The independent variables using a questionnaire characteristic data obtained from medical records and the dependent variable using fatigue assessment scale by the Oncology Nursing Society (ONS) is standard. 


\section{Research Result}

\subsection{Univariate analysis}

a. Age

Table 1. Frequency Distribution of Respondents by Age

\begin{tabular}{cccc}
\hline No. & Age & Frequency (n) & Percentage (\%) \\
\hline 1 & $2-6$ th & 23 & 52.3 \\
2 & $7-9$ th & 9 & 20.5 \\
3 & $10-12$ th & 10 & 22.7 \\
4 & $13-17$ th & 2 & 4.5 \\
\hline & amount & 44 & 100
\end{tabular}

According to the table 1 shows that the age of the child obtained the highest yield ALL cancer aged 2-6 years at $52.3 \%$ (23 respondents).

b. Gender

Table 2. Frequency Distribution of Respondents by Gender

\begin{tabular}{cccc}
\hline No. & Type & Frequency (n) & Percentage (\%) \\
\hline 1 & Sex & 27 & 61.4 \\
2 & Male & 17 & 38.6 \\
\hline & woman & 44 & 100 \\
\hline
\end{tabular}

Based on Table 2 indicate that ALL cancer children showed most having sex men by $61.4 \%$ (27 respondents).

c. Old Treatment

Table 3. Frequency Distribution of Respondents by Old Medicine

\begin{tabular}{cccc}
\hline No. & old Medicine & Frequency (n) & Percentage (\%) \\
\hline 1 & $<2$ years & 26 & 59.1 \\
2 & $\geq 2$ years & 18 & 40.9 \\
\hline & amount & 44 & 100 \\
\hline
\end{tabular}

Based on Table 3 shows that the majority have long treatment results $<2$ years amounted to $59.1 \%$ (26 respondents). 
d. Hemoglobin Values

Table 4. Frequency Distribution of Respondents by Hemoglobin Values

\begin{tabular}{cccc}
\hline No. & $\begin{array}{c}\text { Hemoglobin } \\
\text { Values }\end{array}$ & Frequency (n) & Percentage (\%) \\
\hline 1 & $1-10 \mathrm{~g} / \mathrm{dL}$ & 25 & 56.8 \\
2 & $11-20 \mathrm{~g} / \mathrm{dL}$ & 19 & 43.2 \\
\hline & amount & 44 & 100 \\
\hline
\end{tabular}

Based on Table 4 shows that the value of ALL cancer child hemoglobin showed the majority had $\mathrm{Hb} 1-10 \mathrm{~g} / \mathrm{dL}$ of $56.8 \%$ (25 respondents).

e. Fatigue level

Table 5. Distribution of frequency is of Respondents by Level Fatigue

\begin{tabular}{cccc}
\hline No. & Fatigue level & Frequency (n) & Percentage (\%) \\
\hline 1 & Not tired & 4 & 9.1 \\
2 & Light & 20 & 45.5 \\
3 & moderate & 11 & 25.0 \\
4 & Weight & 6 & 13.6 \\
5 & Very heavy & 3 & 6.8 \\
\hline & amount & 44 & 100 \\
\hline
\end{tabular}

Based on Table 5 shows that the level of fatigue of respondents showed the majority had mild fatigue level of $45.5 \%$ (20 respondents) and others have very severe fatigue level of $6.8 \%$ (3 respondents).

\section{Discussion}

\subsection{Age in children ALL}

The results showed the age of the child undergoinging cancer chemotherapy ALL the most are aged 2-6 years at 52.3\%. At the age of 2-6 years old children are more susceptible to cancer diagnosed ALL. This is consistent with studies that say children age 2-6 years a lot going on ALL cancer [11].

Age will affect a person's immune system so it will affect the body's susceptibility to disease. Children aged less would be more at risk of suffering more severe disease [12].

Solutions that can be given to parents nurses are nurses provide health education on aspects of medical management to strengthen the observance of parents and children to provide treatment if the child is sick. 


\subsection{Gender in children ALL}

The results showed the child sex ALL cancer who undergoing chemotherapy that most of the male sex by $61,4 \%$. This is in line with research Margolin [13] reveals not know the exact cause of the male gender that many cancer ALL.

According to research Jackson [14] Acute leukemia is more common in boys. The results of the study distinguish between blood groups A, B, O in a distribution group of men and women with ALL cancer. The same trend for the proportion of group $\mathrm{O}$ were lower among women than men. The existence of genes A, B, O on chromosome 9 that the relative protection of the blood group $\mathrm{O}$ women having ALL cancer. The existence of such a gene that causes cancer also occurs in ALL many boys. According to research by Chiang Hon et al [5] compared between men and women with ALL cancer. Boys tend to have a T-cell. Differences in men and women contained in the immunophenotype and DNA index.

Risk factors ALL such as genetic factors, family history of acute lymphoblastic leukemia, has a brother or sister with ALL will increase the risk of a child suffering from ALL and a history of mental retardation in children.

\subsection{Treatment of childhood ALL old}

The results showed the duration of treatment of children ALL cancer who undergoing chemotherapy are high is the length of treatment $<2$ years at $59.1 \%$. This is in line with research conducted [15] revealed that ALL children should do therapy treatments for approximately 2 years.

Children who undergoing chemotherapy will surely experience a physiological impact. The physiological impact of chemotherapy in children with leukemia in children with leukemia suffered by children, namely nausea, vomiting, decreased appetite, fatigue [16].

Treatment of children with ALL long as chemotherapy have a significant impact on the psychological status both in children and their parents with a low prevalence of low self-esteem in children and high levels of stress on their parents. Nevertheless the role of parents in the treatment of ALL cancer chemotherapy in children is very important. A mother figure is very important in helping to care, ranging from assisting to deal with side effects and symptoms of chemotherapy such as physical disorders, psychological, and social development. [11], [17].

Children who undergoing chemotherapy treatment that long should be given to growth stimulation. One of the stimulation of growth that can be given to a child is play therapy. Play therapy is believed to be able to remove the restrictions, barriers themselves, and stress. Activities play performed in children hospital nurse is giving the child a game in order to work with, more cooperative in a given game [18].

The public and health professionals is important to understand the types of social support to parents of friends and family. pemebrian social support which they felt did not help and help them cope with and adapt them after the crisis of childhood cancer diagnosis. social support to help them cope with and adjust to the diagnosis. The results showed important implications for individuals who want to help families cope with and adapt to the children's cancer to educate family, friends, and members of the public about effective social support.

The main role of the nurse is to provide health services to meet the needs sharpening, compassion, and care. Nurses can also provide supportive care-educative to help children 
achieve the possibility of higher levels of health and well-being [20]. The parents, especially the mother as pembberi primary care is very important to receive support information and emotional of a husband, a fellow had a child with cancer, and health care workers, because this support can lower the anxiety levels of mothers and contribute to the welfare and quality of life of children [21].

Stimulation of growth that can be given to children undergoinging prolonged treatment is to explore in terms of games. The role of the nurse for children undergoinging disease and cancer treatment is to minimize the complications of medical therapy or chemotherapy, prevent infection, prevent injury from bleeding, immobility, maintain adequate nutrition, preventing mucositis, prevent pain, help the family in using coping adaftif against childhood diseases [22].

\subsection{Hemoglobin Values in children ALL}

The results showed most of the children hemoglobin value is $1-10 \mathrm{~g} / \mathrm{dL}$ of $56.8 \%$. Supporting research suggested by Sharon [6] which revealed that children with ALL cancer had hemoglobin levels to the lowest value of $6.4 \mathrm{~g} / \mathrm{dL}$ and the highest $12.5 \mathrm{~g} / \mathrm{dL}$. The impact of a low hemoglobin level in children will lead to a lack of oxygen to the entire body so that it will interfere with the performance of the body. The body will feel weak, less vibrant, less powerful, and it's hard to concentrate [23]. One of the symptoms of low hemoglobin level in children ALL is a child will experience fatigue. Actions that can be done if a child suffering from fatigue is to give the child to rest, restrict activity, especially strenuous [24].

When Low hemoglobin levels to all parents of children can perform the act of giving children foods that contain iron. If there is no increase in hemoglobin levels after consuming the food iron, parents should bring their children to the nearest health service to do further handling eg blood transfusion [25]. The nurse's role in this is to provide information to the parents of the dangers of a low hemoglobin level in children in order to avoid the possibility of further effects.

\subsection{Fatigue level in ALL children}

The results showed a rising scale fatigue ALL children undergoinging chemotherapy cancer at $45,5 \%$. This is in line with that proposed by [26] children will offer a different perspective on fatigue in accordance with the age and stage of development. Younger children $(<9$ years) revealed that fatigue affects their ability in physical activity. The impact of fatigue on ALL children among other children will experience growth disorders, memory loss, short term memory limitations (easily forgotten), and learning difficulties [27].

The role of parents in dealing with children who have fatigue are limiting the playing time on the child so that the child has adequate rest time [28]. Some of the ways that can be used for. Nurses also have an important role in dealing with children who have exhausted child's fatigue as advised children to nap or rest, do some light exercise if possible like a walk [29]. 


\section{Acknowledgment}

Researchers would like to thank profusely to the Rector and dean of medical faculty and the University of Sari Mulia Sari Mulia University research institute that has been granted permission to raise the issue to be researched, the hospital director and head of training Ulin has given permission to conduct this research

\section{References}

[1] World Health Organization. Estimated Cancer Incidence, Mortality and Prevalence Worldwide in 2012 from International Agency for Research on Cancer World Health Organization. [Internet] Tersedia dalam: http://globocan.iarc.fr/Pages/fact_sheets_cancer.aspx. [Diakses tanggal 21 Januari 2017]. (2012).

[2] Rudolph , A. M., Hoffman, J. I. E. Buku Ajar Pediatric Rudolph. Jakarta: EGC. (2007).

[3] Simanjorang, C. dkk. Gambaran Epidemologi Kasus Leukemia Anak di Rumah Sakit Kanker Dharmais. Jakarta: Fakultas Kesehatan Masyarakat Universitas Indonesia. (2010).

[4] National Comprehensive Cancer Network (NCCN). Clinical Practice Guidelines In Oncology.[Internet]Tersediadalam.http//:www.nccn.org/professionals/physician_gls/pdf/fatigue.pd f. [Diakses 18 Oktober 2017]. (2014).

[5] Ching-Hon Pui, James M. Boyett, Mary V. Relling, Patricia L. Harrison, Gaston K. Rivera, Frederick G. Behm, John T. Sandlund, Raul C. Ribeiro, Jeffrey E. Rubnitz, Amar Gajjar, and William E. Evans. Sex Differences in Prognosis for Children With Acute Lymphoblastic. J. Clin Oncol, 17:3, 818-818-824. (1999).

[6] Sharon, T. dkk. Hubungan Kadar Hemoglobin Dengan Peluang Remisi Pada Anak Penderita Leukemia Limfoblastik Akut Periode 2010-2014 di RSUP Prof. dr. R. D. Kandou Manado. Manado: Fakultas Kedokteran Universitas Sam Ratulangi Manado. (2014).

[7] Faozi, M., Saleh, M., Wakil, M.E., Monir, Z., Eltahlawy, E. Quality Of Life In Egyptian Children With Cancer. Journal Of Cancer Therapy. 4:1256-1261. (2013).

[8] Yeh CH, Chiang YC, Lin L, Yang CP, Chien LC, Weaver M, et al. Clinical factors associated with fatigue over time in paediatric oncology patients receiving chemotherapy. British Journal of Cancer. 2008;99(1):23-9. (2008).

[9] Lameshow, S., Hoemer Jr, D.W., Klar J., Lwanga, S.K. Pengambilan Sampel. In: Kusnanto H, eds. Besar Sampel dalam Penelitian kesehatan. 1st ed. Yogyakarta: Universitas Gadjah Mada Press. 1997:1-30. (1997).

[10] Sugiyono. Memahami Penelitian Kualitatif. Bandung: Alfabeta. (2012).

[11] Wong D.L, Hockenberry M, et al. Buku Ajar Keperawatan Pediatric. Jakarta: EGC. (2009).

[12] Permono B., Sutaryo., Ugrasena., W, Endang., Abdul Salam,A. Buku Ajar Hematologi-Onkologi Anak. Penerbit: Badan Penerbit IDAI. (2006).

[13] Margolin FJ, Stueber CP et al. Acute Lymphoblastic Leukemia. Hal: 53-90. (2011).

[14] Jackson N, Zarina W et al. Why is Acute Leukemia More Common in Males ? A Possible sexdetermined risk linked to the ABO blood group genes. Vol 78: 233-236. (1999).

[15] Cooper, S. L., \& Brown, P. A. Treatment of pediatric acute lymphoblastic leukemia. Pediatric clinics of North America. 62(1). 61-73. (2015).

[16] Herfiana, S. Dampak Fisiologis Kemoterapi pada Anak dengan Leukemia di Rumah Sakit Umum Daerah Dr. Moewardi [Thesis]. Surakarta. Universitas Muhammad Surakarta. (2017).

[17] Sherief, L. M., Kamal, N. M., Abdalrahman, H. M., Youssef, D. M., Abd Alhady, M. A., Ali, A. S. Hashim, H. M. Psychological Impact of Chemotherapy for Childhood Acute Lymphoblastic Leukemia on Patients and Their Parents. Medicine. 94(51), e2280. (2015).

[18] Mulyaman. I. Terapi Bermain untuk Mengurangi Tingkat Kecemasan Akibat Hospitalisasi pada Anak Usia Sekolah [Internet]. Tersedia dalam: http//: www.ugm.ac.id [diakses 2 Agustus 2018]. (2006).

[19] Zomerlei, D. R.Family Resilience Following A Diagnosis Of Pediatric Cancer: Parent Experiences Of Social Support, Coping, And Adaptation. A DISSERTATION unpublished. Submitted to 
Michigan State University in partial fulfillment of the requirements for the degree of Human Development and Family Studies - Doctor of Philosophy. (2015).

[20] Berman. Synder. Buku Ajar Fundamental Keperawatan Konsep Proses dan Praktik Vol 1 Edisi 7. Jakarta: EGC. (2010).

[21] Fetriyah, UH., Mulatsih, S., dan Pangastuti, H. Relationship Between Social Support and Anxiety of Mothers Treating Child With Cancer. [Internet]. Tersedia dalam: http://www.atlantispress.com/proceedings/smichs-17/25886813. [Diakses 9 Agustus 2018]. (2017).

[22] Muscari, Mary, E. Panduan Belajar Keperawatan Pediatric. Jakarta: EGC. (2005).

[23] Arisman. Buku Ajar Ilmu Gizi. Jakarta: EGC. (2009).

[24] American Cancer Society. Cancer Facts \& Figures 2015. [Internet] Tersedia dalam : American Cancer Society, Inc.: http://www.cancer.org. [Diakses 11 Oktober 2017]. (2016).

[25] Hetty. Pengaruh Jus Kacang Hijau Terhadap Kadar Hemoglobin dan Jumlah sel Darah dalam Konteks Asuhan Keperawatan Pasien Kanker dengan Kemoterapi. Jakarta: Program Pasca Sarjana Fakultas Ilmu Keperawatan Universitas Indonesia. (2008).

[26] Chiang $\mathrm{YC}$, Yeh $\mathrm{CH}$, Wang $\mathrm{KWK}$, Yang CP. The experience of cancer-related fatigue in Taiwanese children Eur J Cancer Care (in press). (2008).

[27] Allenidekania., Rahmawaty, F., \& Waluyanti, F. T. Sleep Disturbances and Fatigue in Adolescent with Cancer Receiving Chemotherapy. Makara J. Health Rest. Vol 18 (2): 87-94. (2015).

[28] Vitkauskaite, E., Jouzaityte, E., Drukteniene, J., \& Bunevicius, R. A Systematic review of Cancer Related Fatigue. Biological Psychiatry and Psychopharmalogical Journal. Vol 13: 74-77. (2011).

[29] Loprinzi, C. L., Bensinger, W. I., Peterson, D. E., \& Messner, C. Understanding and Managing Chemotherapy Side Effects. New York: Cancer Care. (2014). 